\title{
Rasulullah Saw. dan Pencegahan Wabah Covid-19: Studi Tematik Hadis-hadis Penyakit Menular
}

\author{
Dede Mardiana \\ Program Studi Ilmu Hadis \\ Fakultas Ushuluddin UIN Sunan Gunung Djati Bandung, Indonesia \\ dedemardiana022@gmail.com
}

\begin{abstract}
This research was motivated by the outbreak of Covid-19 that occurred in various parts of the world, including Indonesia. This study aims to discuss the practice of the Prophet Muhammad according to the hadith regarding disease outbreaks regarding the prevention of the Covid-19 pandemic. This research is a qualitative research through literature study using the syarah hadith method with a thematic approach. The results and discussion of this research show that the practice of the Prophet Muhammad according to the hadith themes of disease outbreaks after sharah, including social infections, quarantine for the infected, and taking treatment as a preventive and cure, where this is a practice applied in the prevention of the Covid-19 pandemic in the modern era. This study concludes that the Prophet's practice with regard to the prevention of infectious diseases according to syarah has been implemented as the most effective step to break the chain of the spread of the Covid-19 infectious disease that is happening in various parts of the world including Indonesia.
\end{abstract}

Keywords: Covid-19, Hadith, Plague, Syarah, Thematic Method.

\begin{abstract}
Abstrak
Penelitian ini dilatarbelakangi oleh mewabahnya Covid-19 yang terjadi di berbagai belahan dunia termasuk Indonesia. Penelitian ini bertujuan untuk membahas praktik Rasulullah Saw. menurut hadis tentang wabah menular berkenaan dengan pencegahan pandemi Covid-19. Penelitian ini merupakan jenis kualitatif melalui studi pustaka dengan menggunakan metode syarah hadis pendekatan tematik. Hasil dan pembahasan penelitian ini menunjukan bahwa praktik Rasulullah Saw. menurut tema-tema hadis tentang wabah menular setelah dilakukan syarah meliputi pembatasan sosial, karantina bagi yang terjangkit, dan
\end{abstract}


melakukan pengobatan sebagai preventif dan penyembuhan, dimana hal ini menjadi praktik yang diterapkan dalam pencegahan pandemi Covid-19 di era modern. Penelitian ini menyimpulkan bahwa hadis-hadis Rasulullah Saw. berkenaan dengan pencegahan wabah penyakit menular menurut syarah hadis dipahami sebagai langkah paling efektif untuk memutus mata rantai penyebaran wabah penyakit menular Covid-19 yang sedang terjadi di berbagai belahan dunia termasuk Indonesia.

Kata kunci: Covid-19, Hadis, Metode Tematik, Syarah, Wabah.

\section{Pendahuluan}

Pada saat ini manusia tengah dilanda wabah penyakit menular, yaitu wabah Coronavirus Disease (Covid-19). Covid-19 berasal dari Wuhan, Tiongkok (Darmalaksana, Corona Hadis, 2020). Dalam beberapa media massa dan pengamatan para ahli kesehatan bahwa Covid-19 pada mulanya ditularkan dari hewan kepada manusia, namun pada saat ini Covid-19 telah menular dari manusia ke manusia (Nurhayati, 2020). Ribuan manusia meninggal dunia di berbagai negara karena Covid-19 sehingga organisasi kesehatan WHO (World Health Organization) mengindikasikan Covid-19 sebagai pandemi dan menghimbau darurat kesehatan masyarakat yang menjadikan semua pihak turun tangan memerangi wabah yang menular ini. Pencegahan dan penanganan dilakukan di berbagai negara dengan menerapkan perubahan sosial dalam kehidupan bermasyarakat agar penyebaran Covid-19 dapat dihentikan (Sihab, 2020). Perubahan sosial mulai dilakukan oleh pemerintah Indonesia dengan menerapkan protokol kesehatan sebagai kehidupan bermasyarakat yang baru, seperti menggunakan masker ketika beraktivitas, menjaga jarak atau sosial distancing, mencuci tangan menggunakan cairan anti septik dan pengecekkan suhu tubuh ketika mengunjungi suatu tempat sebagai bentuk pencegahan dan penanganan penyebaran Covid-19 (Andrija, 2020). Praktik Rasulullah Saw. yang terakumulasi dalam hadis sebagai hujjah pedoman umat muslim kedua setelah al-Qur'an mempunyai isi kandungan yang komprehensif dalam mengatasi berbagai permasalahan di segala zaman (Kholis, Hermeneutika Hadis, 2013). Berkaitan dengan ini, metode pemaknaan hadis telah dikembangkan oleh para ulama sejak masa klasik melalui pemahaman yang mendalam dengan berbagai macam pendekatan (Mosiba, 2016). Isi kandungan hadis diakui sebagai informasi dalam menghadapi situasi dan kondisi di masa depan. Termasuk tentang praktik pencegahan wabah Covid-19 (Mukharom, 2020). 
Penelitian yang dilatarbelakangi Covid-19 sedang terus berlangsung, literatur kesilaman yang berkaitan dengan Covid-19 juga semakin berkembang. Antara lain penelitian yang dilakukan oleh Darmalaksana (2020), dengan judul "Corona Hadis," dalam Jurnal Fakultas Ushuluddin UIN Sunan Gunung Djati Bandung. Penelitian ini bertujuan untuk membahas Covid-19 dalam perspektif hadis. Penelitian ini bersifat kualitatif melalui studi pustaka atau conten analisis. Hasil dan bahasan penelitian ini yakni ada hadis yang secara tegas berkaitan dengan isolasi, karantina dan social distancing. Penelitian ini menyimpulkan bahwa perang lawan Corona melalui social distancing dan isolasi telah diisyaratkan oleh hadis (Darmalaksana, 2020). Ada pula penelitian yang dilakukan oleh Khaeruman, Nur, Mujiyo, Rodliyana (2020), dengan judul "Pandemi Covid-19 dan Kondisi Darurat: Kajian Hadis Tematik," KTI Ilmu Hadis UIN Sunan Gunung Djati Bandung. Penelitian ini bertujuan untuk mengungkap kebijakan pemerintah Republik Indonesia dalam mengatasi pandemi Covid-19 dengan mengajukan hadis untuk penanganan Covid-19 dan keadaan darurat. Penelitian ini bersifat kualitatif dengan menggunakan studi pustaka dan analisis kritis. Hasil pembahasan penelitian ini yaitu social distancing dan tes massal sangat efektif untuk memutus mata rantai Covid-19. Kesimpulan penelitian ini yaitu pencegahan penyakit menular seperti social distancing sudah diisyaratkan sejak Rasulullah masih hidup melalui hadis-hadisnya (Mukharom, 2020). Lalu Mukharom Aravik (2020), dengan judul “Kebijakan Nabi Muhammad Saw. Menangani Wabah Penyakit Menular dan Implementasinya dalam Menangani Corona Virus Covid-19," Jurnal SALAM UIN Syarif Hidayatullah Jakarta. Penelitian ini bersifat deskriptif kualitatif. Hasil pembahasan penelitian ini yaitu bahwa wabah Covid-19 relevan dengan wabah Thaun pada masa Rasulullah dan pencegahannya juga mengisyaratkan pembatasan sosial. Kesimpulan penelitian ini yaitu kebijakan yang diberlakukan pada saat ini relevan dengan kebijakan Nabi Muhammad Saw. dalam hadis tersebut (Mukharom, 2020).

Berdasarkan tinjauan pustaka di atas, relevansi penelitian ini dengan penelitian terdahulu yakni pada topiknya mengenai hadis tentang pencegahan Covid-19. Sedangkan perbedaannya, penelitian ini mencoba mengkaji hadis-hadis tentang konsep pencegahan Covid-19 secara tematik (maudu'i) yang mana fokus penelitian ini untuk mengetahui praktik pencegahan Covid-19 dalam hadis tersebut dengan mengkaji syarah dan juga mensintesis hasil penelitian-penelitian terdahulu agar terciptanya sebuah pengetahuan baru mengenai hadis-hadis tentang praktik pencegahan wabah Covid-19 dengan mengacu pada kitab-kitab mashadir asliah hadis.

Kerangka berfikir penelitian ini disusun dengan melihat penelitianpenelitian sebelumnya dan mencoba mengembangkan serta 
mensintesisnya agar dapat menghasilkan pengetahuan yang baru. Penyakit menular adalah jenis penyakit yang hidup dan bisa berpindah dari suatu habitat ke habitat yang lain dan dari satu orang ke orang yang lainnya baik melalui perantara maupun tanpa perantara (Chandra, 2013). Keberadaan penyakit menular pada tubuh manusia dapat mengakibatkan infeksi bahkan agen infeksi tersebut bisa menjalar terhadap individu yang sehat dan terjadilah penularan penyakit (Effendi, Pencegahan Penyakit Menular, 1987). Pandemi dan epidemi termasuk pada penyakit menular, organisasi kesehatan WHO menyebutkan sebutan pandemi bukanlah dilihat dari berapa banyak yang terpapar dan kondisi terparah suatu wabah melainkan dilihat dari kondisi geografisnya yakni seberapa luasnya wabah penyakit tersebut menjalar (Noor P. D., 2014). Sedangkan epidemi adalah kondisi dimana wabah penyakit menular menjalar dengan cepat pada suatu negara dan menimbulkan banyak korban jiwa (Noor P. D., 2014). Pemerintah Republik Indonesia menerapkan social distancing, physical distancing dan karantina mandiri sebagai preventif Covid-19 (Sihab, 2020). Social distancing adalah pembatasan interaksi sosisal untuk memutus mata rantai pencegahan Covid-19, physical distancing atau isolasi ialah keadaan memisahkan antara yang sakit dengan yang sehat, adapun karantina adalah keadaan dimana seseorang yang berpotensi terjangkit Covid-19 yang diharuskan memisahkan diri dahulu dari khalayak ramai (Darmalaksana, 2020). Model pencegahan ini selaras juga dengan fatwa Imam Ibnu Hajar al-Atsqalani dalam kitabnya Badzlu al-Maa'un fi Fadhl atTha' un yang melarang perkumpulan orang-orang banyak demi mencegah penularan penyakit Thaun yang sedang melanda Syam pada masa kepemimpinan Umar bin Khattab (Contrad, 2020).

Rumusan masalah penelitian ini adalah terdapatnya hadis Rasulullah Saw. berkenaan dengan pencegahan wabah penyakit menular. Pertanyaan penelitiannya yaitu apa saja hadis Nabi tentang wabah dan bagaimana kualitasnya, dan bagaimana implementasi hadis tentang wabah untuk pencegahan Covid-19 di masa kini. Penelitian ini bertujuan untuk membahas praktik Rasulullah Saw. menurut hadis tentang wabah menular berkenaan dengan pencegahan pandemi Covid-19. Penelitian ini diharapkan memiliki implikasi manfaat bagi pengembangan khazanah pengetahuan Islam.

\section{Metode Penelitian}

Penelitian ini menggunakan jenis kualitatif yang bertujuan mendeskripsikan data yang dihimpun dari penelusuran sumber kepustakaan (Darmalaksana, 2020). Terhadap penelitian hadis yang menjadi bidang utama penelitian ini diterapkan tiga metode yang dijalankan secara bertahap, yaitu tematik, takhrij, dan syarah (Darmalaksana, 2020). Pertama, metode tematik, hal ini digunakan untuk 
melacak, menghimpun, dan menentukan tema-tema hadis berkaitan dengan topik penelitian (Abdullah, 2021). Kedua, metode takhrij, hal ini digunakan untuk mengumpulkan hadis dari kitab mashadir ashliyah hadis menyangkut tema-tema yang berkaitan dengan topik penelitian hadishadis pencegahan penyakit menular sehingga diketahui status, kualitas, dan kedudukan hadis (Izzan, 2012). Ketiga, metode syarah, hal ini digunakan untuk mengetahui penjelasan para ulama terkait tema hadis yang sedang dibahas (Darmalaksana, 2020). Tiga metode ini dijalankan menjadi satu kesatuan yang tidak terpisahkan dalam menghasilkan temuan penelitian. Terakhir, terhadap hasil temuan penelitian dilakukan analisis (interpretasi) untuk menghasilkan pengetahuan hingga ditarik sebuah kesimpulan penelitian (Darmalaksana, 2021). Adapun pada tahap interpretasi digunakan beberapa analisis (pendekatan), seperti historis, $a b a b$ al-wurud, dan isu kontemporer (Darmalaksana, 2020).

\section{Hasil dan Pembahasan}

Hasil dan pembahasan penelitian di bawah ini.

\section{Tinjauan Umum Wabah dan Pandemi}

Bagian ini membahas pengertian wabah dan pandemi, rekam jejak wabah dan pandemi, dan preventif Covid-19 di Indonesia.

\section{a) Pengertian Wabah dan Pandemi}

Pandemi termasuk penyakit infeksi yang mewabah dalam kurun waktu cepat sekali juga menjangkit secara bersamaan di setiap belahan bumi. Penyakit menular atau wabah adalah virus racun yang dapat ditularkan langsung pada manusia atau tidak langsung melalui reservoir dan vector penyakit (Effendi, 1987). Sedangkan wabah adalah kondisi dimana penyakit menular dikategorikan sebagai penyakit luar biasa.

Sementara itu, hal yang seringkali dikaitkan dengan pandemi adalah epidemi, namun keduanya mempunyai perbedaan. Epidemi lebih fokus pada berjangkitnya suatu penyakit pada sekelompok orang di masyarakat dengan jenis penyakit, waktu dan sumber yang sama dan terjadi diluar keadaan biasa atau kejadian luar biasa (Chandra, 2013). Adapun pandemi ialah wabah yang terjadi secara bersamaan di seluruh dunia atau meliputi geografis yang luas (Chandra, 2013).

Wabah menjangkit kepada manusia yang sensitif melalui beberapa cara yang disebut dengan mode of transmission bisa terjadi secara langsung atau melaui perantara. Jika ditinjau dari aspek epidemiolog (cabang ilmu kesehatan untuk menganalilis sifat atau penyebaran penyakit dan berbagai masalah kesehatan) penyebaran penyakit ini dapat bersifat lokal, regional maupun internasional (Noor N. N., 2014). 


\section{b) Rekam Jejak Wabah dan Pandemi}

Wabah dan pandemi bukanlah hal yang baru ditemui dalam sejarah peradaban manusia di bumi ini. Wabah menular dalam dunia kesejarahan Islam dikenal dengan Tha'un. Sejarah Islam mengakui ada kurang lebih lima pandemic Tha'un yang paling besar dan paling banyak merenggut nyawa. Pertama ada Tha'un al-Asyraf yang merenggut orang-orang penting, kedua, Thau'n Fatayat yang merenggut anak muda, ketiga, Tha'un jarif, keempat, Tha'un amwas pada masa khalifah Umar bin Khatab, lalu yang terakhir, kelima, Tha'un yang terjadi ketika Nabi Muhammad Saw. masih hidup yakni Thau'n syirawaih (Ridho M. R., 2020). Thau'n tidak pernah muncul lagi dalam sejarah hingga muncul wabah Ebola di Afrika Barat yang menarik perhatian publik internasional pada tahun 2014. Virus ini sangat menggegerkan dan menjadi isu internasional yang hangat diperbincangkan, wabah Ebola juga berdampak pada kehidupan sosial masyarakat termasuk bidang ekonomi (Romadona, 2015). Hingga pada tahun 2020 ini muncul lagi pandemi Covid-19 yang menggegerkan semua pihak dunia termasuk Indonesia.

\section{c) Preventif Covid-19 di Indonesia}

Ilmu epidemiologi menyebutkan bahwa keberhasilan manusia dalam menemukan pencegahan penyakit menular atau pandemi dewasa ini merupakan pencapaian yang patut diapresiasi mengingat pandemi ini sangat cepat penularannya (Noor N. N., 2014). Penyakit menular pada manusia yang disebabkan oleh virus, seringkali menimbulkan kecacatan dan bahaya kematian karena tidak ada kekebalan bawaan (alamiah) untuk membunuh virus di samping daya tahan tubuh yang masih lemah. Di Indonesia penyakit yang disebabkan oleh virus banyak ditemukan antara lain seperti poliomyelitis, campak, HIV, Demam Berdarah Dengue (DBD), hepatitis dan virus yang sekarang sedang menjangkit yakni virus Covid-19.

Indonesia mulai melakukan penanganan dengan menerapkan PSBB (Pembatasan Sosial Berskala Besar) dan local lockdown di beberapa wilayah. Untuk menghentikan mata rantai penyebaran Covid-19. Namun karena penerapan ini mengakibatkan banyaknya orang yang mulai kesulitan dalam memenuhi kebutuhan sehari-hari, pengangguran semakin meningkat dan lain-lainnya, maka diterapkanlah New Normal (Normal Baru) yang merupakan suatu sistem baru dari pemerintah dengan tujuan untuk mempertahankan perekonomian di tengah pandemi dengan mencoba mengembalikan aktivitas seperti biasa dengan memperhatikan protokol kesehatan. Pemerintah juga menghimbau $3 \mathrm{M}$, yaitu mencuci tangan, memakai masker, dan menjaga jarak.

Sebagai preventif Covid-19, pemerintah Indonesia menerapkan protokol kesehatan dalam bentuk kehidupan bermasyarakat yang baru, 
seperti menggunakan masker ketika beraktivitas, menjaga jarak atau sosial distancing, mencuci tangan menggunakan cairan anti septik dan pengecekkan suhu tubuh ketika mengunjungi suatu tempat sebagai bentuk pencegahan dan penanganan penyebaran Covid-19 (Muhyiddin, 2020). Dalam beribadah penerapan protokol kesehatan senantiasa diterapkan tanpa terkecuali sehingga menjalankan ibadah di mesjid pun mengalami perubahan dalam pelaksanaanya, sepeti menjaga jarak ketika shalat, menggunakan masker, mencuci tangan dan pengecekkan suhu badan ketika masuk masjid. Penerapan protokol kesehatan dilakukan oleh masyarakat sebagai bentuk kepedulian atas pencegahan penyebaran Covid-19 (Zaenuri, 2020). Sebagai upaya mencegah penularan Sars-CoV-2, pemerintah mendesak publik untuk mengisolasi diri atau isolasi mandiri. Juru bicara Kementrian Kesehatan Covid-19 Ahmad Yurianto, sampaikan esensi utama isolasi mandiri untuk mencegah potensi adanya penyebaran virus ke orang sekitar (Andrija, 2020).

Menurut epidemiologi, prinsip dasar penanganan wabah biasanya sama, terkhusus untuk wabah pandemi penyakit menular beberapa terminologi harus diberi perhatian lebih di antaranya kontak, masa penularan, masa inkubasi infeksi, isolasi, dan karantina. Demi mencegah wabah dan pandemi yang akan datang WHO menyarankan negara-negara menyimpan persediaan vaksin dan menanam modal untuk penelitian dan produksi obat di negara mereka masing-masing (Piddock, 2013).

\section{Tema-tema Hadis Pencegahan Wabah}

Sebagai sumber hukum kedua setelah al-Qur'an, hadis mempunyai isi kandungan yang komprehensif mencakup informasi dalam menghadapi permasalaham di segala zaman begitupula mengenai informasi praktik pencegahan penyakit menular yang sudah diinformasikan oleh hadis Rasulullah Saw. sebagai berikut:

Tabel 1. Tema-tema Hadis tentang Wabah

\begin{tabular}{|c|l|l|l|}
\hline No. & \multicolumn{1}{|c|}{ Redaksi Matan Hadis } & \multicolumn{1}{|c|}{ Tema } & \multicolumn{1}{c|}{$\begin{array}{c}\text { Nomor } \\
\text { Hadis }\end{array}$} \\
\hline 1. & $\begin{array}{l}\text { Abdurrahman bin Auf mengabarkan } \\
\text { bahwa Rasulullah shallallahu 'alaihi wa } \\
\text { sallam bersabda "Jika kalian mendengar } \\
\text { wabah tersebut menjangkiti suatu negeri, } \\
\text { maka janganlah kalian menuju ke sana, } \\
\text { namun jika dia menjangkiti suatu negeri } \\
\text { dan kalian berada di dalamnya, maka } \\
\text { janganlah kalian keluar dan lari darinya." }\end{array}$ & Pesial \\
\hline
\end{tabular}




\begin{tabular}{|l|l|l|l|}
\hline 2. & $\begin{array}{l}\text { Abu Salamah bin Abdurrahman berkata: } \\
\text { saya mendengar Abu Hurairah dari Nabi } \\
\text { shallallahu 'alaihi wa sallam beliau } \\
\text { bersabda: } \\
\text { "Janganlah kalian mencampurkan antara } \\
\text { yang sakit dengan yang sehat." }\end{array}$ & $\begin{array}{l}\text { Karantina } \\
\text { mandiri }\end{array}$ & $\begin{array}{l}\text { Shahih } \\
\text { Bukhari } \\
5330\end{array}$ \\
\hline 3. & $\begin{array}{l}\text { Dari Abu Ad Darda ia berkata: } \\
\text { Rasulullah shallallahu 'alaihi wa sallam } \\
\text { bersabda: } \\
\text { penyakit dan obat, dan menjadikan bagi } \\
\text { setiap penyakit terdapat obatnya, maka } \\
\text { berobatlah dan jangan berobat dengan } \\
\text { sesuatu yang haram!" }\end{array}$ & $\begin{array}{l}\text { Anjuran } \\
\text { berobat }\end{array}$ \\
\hline
\end{tabular}

Pada Tabel 1. menunjukan terdapat 3 (tiga) hadis tentang pencegahan wabah yakni pembatasan sosial, karantina mandiri, dan anjuran untuk berobat. Data ini diperoleh melalui penelusuran dalam Kutub al-Tis'ah sebagai mashadir asliah. Hadis-hadis ini diklasifikasikan melalui pendekatan tematik. Teks hadis tersebut terdapat pada kitab Shahih Bukhari, dan Sunan Abu Dawud matannya memuat tema-tema praktik pencegahan wabah menular.

Tema-tema hadis menyangkut pencegahan wabah melalui penelusuran dengan metode tematik akan disajikan melalui metode takhrij dan syarah hadis sebagaimana sajian di bawah ini.

\section{a) Pembatasan Sosial}

Berikut redaksi hadis Rasulullah berkenaan dengan pembatasan sosial bagi wilayah yang terjangkit wabah.

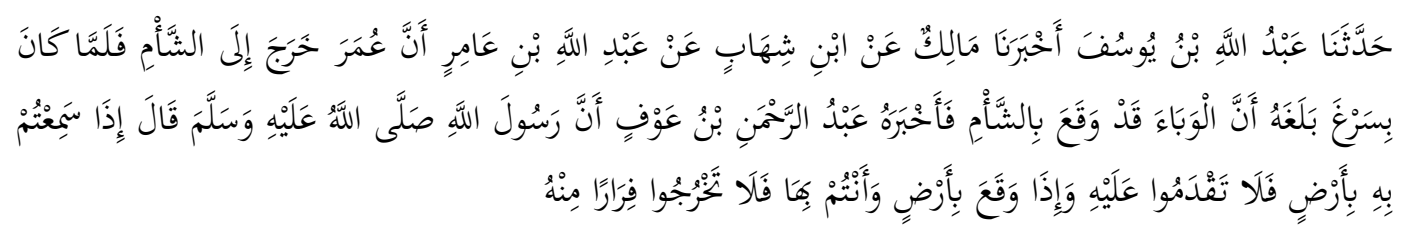

Shahih Bukhari 5289: Telah menceritakan kepada kami Abdullah bin Yusuf telah mengabarkan kepada kami Malik dari Ibnu Syihab dari Abdullah bin 'Amir bahwa Umar pernah bepergian menuju Syam, ketika dia sampai di daerah Sargha, diberitahukan kepadanya bahwa negeri Syam sedang terjangkiti wabah penyakit menular, lantas Abdurrahman bin 'Auf memberitahukan kepadanya bahwa Rasulullah shallallahu 'alaihi wa 
sallam bersabda: "Jika kalian mendengar wabah tersebut menjangkiti suatu negeri, maka janganlah kalian menuju ke sana, namun jika dia menjangkiti suatu negeri dan kalian berada di dalamnya, maka janganlah kalian keluar dan lari darinya" (Bukhari).

Tabel 2. Daftar Rawi dan Sanad

\begin{tabular}{|c|c|c|c|c|c|}
\hline Nama & Kunyah & Kalangan & $\begin{array}{l}\text { Negeri } \\
\text { Hidup }\end{array}$ & $\begin{array}{l}\text { Tahun } \\
\text { Wafat }\end{array}$ & $\begin{array}{l}\text { Komentar } \\
\text { Ulama }\end{array}$ \\
\hline $\begin{array}{l}\text { Abdur } \\
\text { Rahman bin } \\
\text { 'Auf bin } \\
\text { 'Abdi 'Auf } \\
\text { bin 'Abdi } \\
\text { bin al- } \\
\text { Harits bin } \\
\text { Zahrah }\end{array}$ & $\begin{array}{l}\text { Abu } \\
\text { Muhammad }\end{array}$ & Shahabat & Madinah & $32 \mathrm{H}$ & $\begin{array}{l}\text { Ibnu Hajar al- } \\
\text { 'Asqalani } \\
\text { menyebutkan } \\
\text { bahwa ia } \\
\text { hafidz mutqin } \\
\text { dan seorang } \\
\text { tokoh }\end{array}$ \\
\hline $\begin{array}{l}\text { Abdullah } \\
\text { bin 'Amir } \\
\text { bin Rabi'ah }\end{array}$ & $\begin{array}{l}\text { Abu } \\
\text { Muhammad }\end{array}$ & $\begin{array}{l}\text { Tabi'in } \\
\text { kalangan } \\
\text { tua }\end{array}$ & Madinah & $85 \mathrm{H}$ & $\begin{array}{l}\text { Ibnu Hajar al- } \\
\text { Atsqalani } \\
\text { menyebutkan } \\
\text { bahwa ia lahir } \\
\text { pada masa } \\
\text { Rasulullah } \\
\end{array}$ \\
\hline $\begin{array}{l}\text { Muhammad } \\
\text { bin Muslim } \\
\text { bin } \\
\text { 'Ubaidillah } \\
\text { bin } \\
\text { 'Abdullah } \\
\text { bin Syihab }\end{array}$ & Abu Bakar & $\begin{array}{l}\text { Tabi'ut } \\
\text { Tabi'in } \\
\text { kalangan } \\
\text { pertengahan }\end{array}$ & Madinah & $124 \mathrm{H}$ & $\begin{array}{l}\text { Adz-Dzahabi } \\
\text { berpendapat } \\
\text { bahwa ia } \\
\text { seorang tokoh }\end{array}$ \\
\hline $\begin{array}{l}\text { Malik bin } \\
\text { Anas bin } \\
\text { Malik bin } \\
\text { Abi 'Amir }\end{array}$ & $\begin{array}{l}\text { Abu } \\
\text { 'Abdullah }\end{array}$ & $\begin{array}{l}\text { Tabi'ut } \\
\text { Tabi'in } \\
\text { kalangan } \\
\text { tua }\end{array}$ & Madinah & $179 \mathrm{H}$ & $\begin{array}{l}\text { Muhammad } \\
\text { bin Sa'd } \\
\text { berpendapat } \\
\text { bahwa beliau } \\
\text { tsiqah } \\
\text { ma'mun }\end{array}$ \\
\hline $\begin{array}{l}\text { Abdullah } \\
\text { bin Yusuf }\end{array}$ & $\begin{array}{l}\text { Abu } \\
\text { Muhammad }\end{array}$ & $\begin{array}{l}\text { Tabi'ul Atba' } \\
\text { kalangan } \\
\text { tua }\end{array}$ & Maru & $218 \mathrm{H}$ & $\begin{array}{l}\text { Adz-Dzahabi } \\
\text { menyebutkan } \\
\text { bahwa ia } \\
\text { hafizh }\end{array}$ \\
\hline
\end{tabular}


Tabel 2. Hadis shahih Bukhari Nomor 5289, hal ini dilihat dari proses tahammul wa al-ada' menggunakan hadatsana, akhbarana dan sami'tu yang mengindikasikan bahwa mereka bertemu langsung (Qomarullah, 2016). Hadis riwayat Bukhari ini muttasil (bersambung). Dan juga dilihat dari adanya hubungan antara guru dan murid pada masing-masing perawi dilihat dari negeri hidup dan tahun wafatnya yang sangat memungkinkan terjadinya pertemuan antara guru dan murid. Dan juga tidak terjadi keterputusan sanad (Sanusi, 2014). Para ulama juga menilai para periwayat adalah rawi yang tsiqah (adil dan dhabit) dan juga tidak ditemukan syadz dan illat. Jadi hadis tentang pembatasan sosial ketika terjangkit wabah adalah hadis yang maqbul dan bisa dijadikan hujjah (Birbiq, 2020).

Ibnu Qayim berkata dalam kitab syarah Fath al-Bari bahwa hadis ini dapat difahami secara tekstual sesuai makna sebenarnya bahwa Rasulullah mengajak orang-orang beriman untuk menghindari tempat yang terjangkiti wabah penyakit dan melarang keluar dari sana setelah wabah itu mengjangkit daerah tersebut untuk melindungi dirinya sendiri dan melindungi kemaslahatan orang di sekitarnya (al-'Asqalani, 2010).

Makna hadis tersebut sudah jelas secara tekstual yakni mengenai larangan meninggalkan suatu negeri yang terjangkit wabah dan larangan memasuki negeri tersebut. Dan asbabul wurud hadis tersebut adalah ketika negeri Syam dilanda wabah mematikan yakni penyakit Thaun dan mereka menerapkan lockdown di negeri Syam yang terjangkit wabah dan pada saat itu akan ada pertemuan antar bangsawan di Syam untuk kepentingan pemerintahan, Rasulullah melarang pertemuan tersebut dengan menyerukan hadis yang demikian (Firdaus, 2020).

Untuk mencegah penyebaran wabah yang lebih luas wabah Tha'un tersebut sangat cepat penyebarannya dan sangat membahayakan sampai Imam Ibnu Hajar al-Asqolani menyusun sebuah kitab berkenaan dengan wabah Tha'un tersebut yang berjudul Badzlu al-Maa'uun fi Fadhl at-Tha'uun yang berkenaan dengan wabah penyakit menular (Cornad, 2021). Berikut merupakan ringkasan fatwa Imam Ibnu Hajar al-Asqolani juga melarang perkumpulan orang-orang banyak demi mencegah penularan penyakit Tha'un yang sedang melanda Syam pada saat itu (Rakhmadi, 2020).

Kesimpulan dari apa yang diterangkan oleh al-Imâm al-Hafizh Ibnu Hajar al-Asqalani meliputi beberapa hal. Pertama, sholat di suatu tempat (lapang) dan istighotsah untuk menolak "bila ada wabah (Tha'în) sebagaimana kebiasaan Istisqa" (sebelum berpuasa tiga hari) adalah perbuatan yang berlebihan. Kedua, setelah digelarnya acara sholat dan berdo'a secara berkerumun di Damaskus (Syria) pada tahun 749 beberapa Ulama dan penguasa terjangkit wabah secara bersamaan. Ketiga, setelah orang banyak berdoa di kerumunan menyebabkan lebih banyak orang yang terjangkit dari sebelumnya. Keempat, pada tahun 833 di Kairo terjadi perkumpulan ketika kota tersebut terjangkit wabah, sebelum adanya 
perkumpulan itu orang yang meninggal dunia akibat wabah kurang dari 40, tetapi sejak itu lebih dari 1.000 nyawa bertambah. Kelima, Imam Ibnu Hajar al-Atsqalani adalah ulama yang melarang terjadinya perkumpulan tersebut dan insiden inilah yang menjadi motivasi beliau dalam menyusun kitab Badzlu Maun Fi Fadhli at-Thaun tentang penularan wabah penyakit menular yang sangat ganas dan mengenai pencegahannya (al-'Asqalani, 1989).

\section{b) Karantina}

Berikut redaksi hadis Rasulullah berkenaan dengan karantina yakni pemisahan antara orang yang sehat dengan orang yang berpotensi terjangkit.

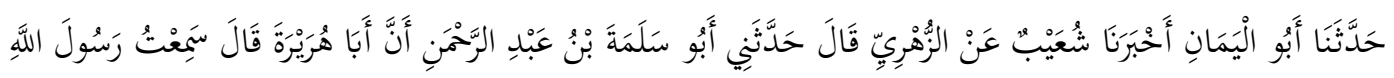

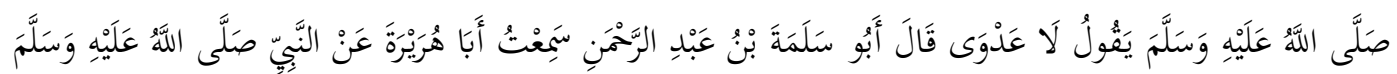

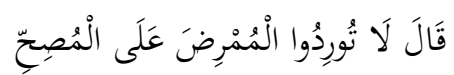

Shahih Bukhari 5330: Telah menceritakan kepada kami Abu AlYaman telah mengabarkan kepada kami Syu'aib dari Az-Zuhri dia berkata: telah menceritaka kepadaku Abu Salamah bin Abdurrahman bahwa Abu Hurairah berkata: saya mendengar Rasulullah shallallahu 'alaihi wa sallam bersabda: "Tidak ada 'adwa (keyakinan adanya penularan penyakit)." Abu Salamah bin Abdurrahman berkata: saya mendengar Abu Hurairah dari Nabi shallallahu 'alaihi wa sallam beliau bersabda: "Janganlah kalian mencampurkan antara yang sakit dengan yang sehat" (Bukhari).

Tabel 3. Daftar Rawi dan Sanad

\begin{tabular}{|l|l|l|l|l|l|}
\hline \multicolumn{1}{|c|}{ Nama } & Kunyah & Kalangan & $\begin{array}{l}\text { Negeri } \\
\text { Hidup }\end{array}$ & $\begin{array}{l}\text { Tahun } \\
\text { Wafat }\end{array}$ & \multicolumn{1}{|c|}{$\begin{array}{c}\text { Komentar } \\
\text { Ulama }\end{array}$} \\
\hline $\begin{array}{l}\text { Abdur } \\
\text { Rahman bin } \\
\text { Shakhr }\end{array}$ & $\begin{array}{l}\text { Abu } \\
\text { Hurairah }\end{array}$ & Shahabat & Madinah & $57 \mathrm{H}$ & $\begin{array}{l}\text { Ibnu Hajar al- } \\
\text { 'Asqalani } \\
\text { menyebutkan ia } \\
\text { dari kalangan } \\
\text { Shahabat }\end{array}$ \\
\hline $\begin{array}{l}\text { Abdullah bin } \\
\text { 'Abdur } \\
\text { Rahman bin } \\
\text { 'Auf }\end{array}$ & $\begin{array}{l}\text { Abu } \\
\text { Salamah }\end{array}$ & $\begin{array}{l}\text { Tabi'in } \\
\text { kalangan } \\
\text { pertengahan }\end{array}$ & Madinah & $94 \mathrm{H}$ & $\begin{array}{l}\text { Abu } \\
\text { menyebutkan } \\
\text { bahwa beliau } \\
\text { tsiqah imam }\end{array}$ \\
\hline
\end{tabular}




\begin{tabular}{|l|l|l|l|l|l|}
\hline $\begin{array}{l}\text { Muhammad } \\
\text { bin Muslim } \\
\text { bin 'Ubaidillah } \\
\text { bin 'Abdullah } \\
\text { bin Syihab }\end{array}$ & $\begin{array}{l}\text { Abu } \\
\text { Bakar }\end{array}$ & $\begin{array}{l}\text { Tabi'ut } \\
\text { Tabi'in } \\
\text { kalangan } \\
\text { pertengahan }\end{array}$ & Madinah & $124 \mathrm{H}$ & $\begin{array}{l}\text { Adz-Dzahabi } \\
\text { menyebutkan } \\
\text { bahwa beliau } \\
\text { seorang tokoh } \\
\text { hebat }\end{array}$ \\
\hline $\begin{array}{l}\text { Syu'aib bin } \\
\text { Abi Hamzah } \\
\text { Dinar }\end{array}$ & $\begin{array}{l}\text { Abu } \\
\text { Bisyir }\end{array}$ & $\begin{array}{l}\text { Tabi'ut } \\
\text { kalangan } \\
\text { tua }\end{array}$ & Syam & $162 \mathrm{H}$ & $\begin{array}{l}\text { lbnu Hibban } \\
\text { menyebutkan } \\
\text { bahwa beliau } \\
\text { disebutkan dalam } \\
\text { 'ats tsiqaat }\end{array}$ \\
\hline $\begin{array}{l}\text { Al-Hakam bin } \\
\text { Nafi' }\end{array}$ & $\begin{array}{l}\text { Abu al- } \\
\text { Yaman }\end{array}$ & $\begin{array}{l}\text { Tabi'ul } \\
\text { Atba' } \\
\text { kalangan } \\
\text { tua }\end{array}$ & Syam & $222 \mathrm{H}$ & $\begin{array}{l}\text { Abu Hatim Ar- } \\
\text { Rozy } \\
\text { menyebutkan } \\
\text { bahwa beliau } \\
\text { Tsiqah Shaduuq } \\
\text { Ibnu Hibban } \\
\text { menyebutkan } \\
\text { bahwa } \\
\text { disebutkan dalam } \\
\text { ats tsiqaat }\end{array}$ \\
\hline
\end{tabular}

Tabel 3. Hadis shahih Bukhari Nomor 5330, hal ini tentang karantina dilihat dari proses tahammul wa al ada' yang menggunakan hadatsana, akhbarana dan sami'tu mengindikasikan bahwa mereka bertemu langsung. Hadis riwayat Bukhari ini muttasil (bersambung). Dan juga dilihat dari adanya hubungan antara guru dan murid pada masing-masing perawi dilihat dari negeri hidup dan tahun wafatnya yang sangat memungkinkan terjadinya pertemuan antara guru dan murid. Dan juga tidak terjadi keterputusan sanad (Wiyono, 2019). Para ulama juga menilai para periwayat adalah rawi yang tsiqah (adil dan dhabit) dan juga tidak ditemukan syadz dan illat. Jadi hadis tentang pembatasan sosial ketika terjangkit wabah adalah hadis yang maqbul dan bisa dijadikan hujjah.

Menurut Ibnu Shalah dalam kitab syarah Fath al-Bari maksud dari redaksi hadis "tidak ada keyakinan tentang adanya penyakit menular" adalah tidak ada penyakit yang menular dengan tanpa sebab. Namun, Allah Ta'alla memberikan alasan penyebaran penyakit, di mana bercampurnya orang sakit dan orang yang sehat. Ada penyebab lain penularan penyakit (kontak fisik, udara). Oleh karena itu, ada peribahasa: "Keluarga fulan terinfeksi penyakit dari keluarga fulan" (al-'Asqalani, 2010). 
Asbabul wurud hadis ini yaitu ketika pada saat itu unta yang dimiliki para kaum Badui terkena penyakit menular dan dikhawatirkan akan menular ke manusia lalu Rasulullah menyeru untuk menjauhi unta tersebut dan memisahkan kandang unta antara yang sudah terjangkit dan unta yang masih sehat dan menyuruh para pemiliknya untuk tidak menengoknya dengan hadis tersebut (al-Asqalani, 2017).

Sebenarnya hadis ini menjadi persoalan karena terdapat redaksi matan yang kontradiktif (Anas, 2013). Persoalan ini dibahas oleh para ulama hadis menggunakan metodenya masing-masing dan pendapat yang paling kuat dijelaskan oleh imam Ibnu Hajar al-Atsqalani yang mengemukakan pendapat yang shahih dan diikuti oleh ulama lain (Mukharom, 2020). Beliau menjalaskan tidak ada nasakh dalam hadis ini kedua redaksinya bisa difahami sebagai perintah menjauhi dan menjaga jarak dengan orang yang sakit sebagai langkah kehati-hatian kita akan terjadinya penularan (Kholis, 2014).

Pada redaksi pertama hadis tersebut Rasulullah seolah mengatakan bahwa tidak ada penyakit menular. Menurut sebagian ulama, redaksi hadits pertama tetap universal tanpa kecuali, sehingga menghilangkan semua penyakit menular, yang berarti tidak ada penyakit menular yang mutlak, seperti yang dikatakan Nabi dalam hadits lain. Begitu pula yang dia katakan kepada orang Baduwi unta tersebut sehat saat dikumpulkan ia mengatakan bahwa unta yang sakit itu terinfeksi beliau bersabda "lalu siapakah yang menulari pertama? (Ghazali, 2020).

Redaksi hadis setelahnya menurut Ibnu Hajar Abu Ubaid perintah untuk menjauh dari pasien adalah Sadd al-Dhara'i' (pengharapan) agar tidak ada prasangka buruk terhadap seseorang jika sewaktu-waktu ada penyakit menular setelah berinteraksi dengan pasien, seseorang jatuh sakit, kalaupun dia sakit bukan karena tertular, tapi karena ditakdirkan untuk sakit oleh Yang Maha Kuasa (al-'Asqalani, 2010).

\section{c) Anjuran untuk Berobat}

Berikut redaksi hadis Rasulullah berkenaan dengan anjuran untuk berobat bagi yang sakit.

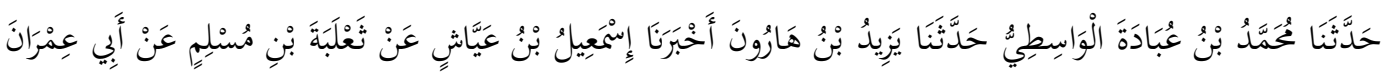

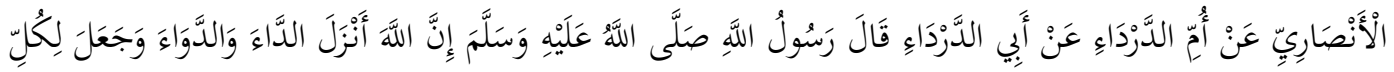

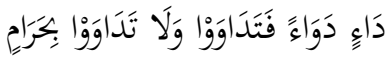

Sunan Abu Daud 3376: Telah menceritakan kepada kami Muhammad bin 'Ubadah al-wasithi telah menceritakan kepada kami Yazid bin Harun telah mengabarkan kepada kami Isma'il bin 'Ayyasy dari Tsa'labah bin Muslim dari Abu Imran al-Anshari dari Ummu ad-Darda dari Abu ad- 
Darda ia berkata: Rasulullah shallallahu 'alaihi wa sallam bersabda: "Sesungguhnya Allah telah menurunkan penyakit dan obat, dan menjadikan bagi setiap penyakit terdapat obatnya, maka berobatlah dan jangan berobat dengan sesuatu yang haram!"

Tabel 4. Daftar Rawi dan Sanad

\begin{tabular}{|c|c|c|c|c|c|}
\hline Nama & Kunyah & Kalangan & $\begin{array}{l}\text { Negeri } \\
\text { Hidup }\end{array}$ & $\begin{array}{l}\text { Tahun } \\
\text { wafat }\end{array}$ & $\begin{array}{l}\text { Komentar } \\
\text { Ulama }\end{array}$ \\
\hline $\begin{array}{l}\text { Uwaimir bin } \\
\text { Malik bin Qais } \\
\text { bin Umayyah bin } \\
\text { 'Amr }\end{array}$ & $\begin{array}{l}\text { Abu ad- } \\
\text { Darda }\end{array}$ & Shahabat & Syam & $32 \mathrm{H}$ & $\begin{array}{l}\text { Ibnu Hajar al- } \\
\text { 'Asqalani } \\
\text { menyebutkan ia } \\
\text { dari kalangan } \\
\text { Shahabat yang } \\
\text { sudah pasti } \\
\text { tsiqah }\end{array}$ \\
\hline $\begin{array}{l}\text { Hubaimah bin } \\
\text { Hayya }\end{array}$ & $\begin{array}{l}\text { Ummu } \\
\text { ad-Darda' }\end{array}$ & $\begin{array}{l}\text { Tabi'in } \\
\text { kalangan } \\
\text { tua }\end{array}$ & Syam & $81 \mathrm{H}$ & $\begin{array}{l}\text { Ibnu Hibban } \\
\text { menyebutkan } \\
\text { bahwa beliau } \\
\text { disebutkan } \\
\text { dalam 'ats } \\
\text { tsiqaat. }\end{array}$ \\
\hline $\begin{array}{l}\text { Sulaim } \\
\text { Abdullah }\end{array}$ & $\begin{array}{l}\text { Abu } \\
\text { 'Imran }\end{array}$ & $\begin{array}{l}\text { Tabi'in } \\
\text { kalangan } \\
\text { biasa }\end{array}$ & Syam & - & $\begin{array}{l}\text { Abu Hatim ar- } \\
\text { Rozy } \\
\text { menyebutkan } \\
\text { bahwa beliau } \\
\text { adalah orang } \\
\text { yang shalih. }\end{array}$ \\
\hline $\begin{array}{l}\text { Tsa'labah bin } \\
\text { 'Amru bin 'Ubaid }\end{array}$ & $\begin{array}{l}\text { Abu } \\
\text { 'Abdullah }\end{array}$ & $\begin{array}{l}\text { Tabi'in } \\
\text { kalangan } \\
\text { biasa }\end{array}$ & Syam & - & $\begin{array}{l}\text { Ibnu Hibban } \\
\text { menyebutkan } \\
\text { bahwa ia adalah } \\
\text { orang yang } \\
\text { tsiqah. }\end{array}$ \\
\hline $\begin{array}{ll}\text { Isma'il } & \text { bin } \\
\text { 'Ayyasy } & \text { bin } \\
\text { Sulaim } & \end{array}$ & $\begin{array}{l}\text { Abu } \\
\text { 'Utbah }\end{array}$ & $\begin{array}{l}\text { Tabi'ut } \\
\text { tabi;in } \\
\text { kalangan } \\
\text { pertengahan }\end{array}$ & Syam & $181 \mathrm{H}$ & $\begin{array}{l}\text { Adz-Dzahabi } \\
\text { menyebutkan } \\
\text { bahwa beliau } \\
\text { adalah alimnya } \\
\text { ahli Syam }\end{array}$ \\
\hline Yazid bin Harun & $\begin{array}{l}\text { Abu } \\
\text { Khalid }\end{array}$ & $\begin{array}{l}\text { Tabi'ut } \\
\text { tabi'in } \\
\text { kalangan } \\
\text { biasa }\end{array}$ & Syam & $206 \mathrm{H}$ & $\begin{array}{l}\text { Ibnu Sa'd } \\
\text { menyebutkan } \\
\text { bahwa beliau } \\
\text { adalah orang } \\
\text { yang tsiqah }\end{array}$ \\
\hline
\end{tabular}




\begin{tabular}{|l|l|l|l|l|l|}
\hline $\begin{array}{l}\text { Muhammad bin } \\
\text { Ubadah bin al- } \\
\text { Mukhtariy }\end{array}$ & $\begin{array}{l}\text { Abu } \\
\text { Abdullah }\end{array}$ & $\begin{array}{l}\text { Tabi'in } \\
\text { kalngan } \\
\text { biasa }\end{array}$ & Syam & - & $\begin{array}{l}\text { Abu Dawud } \\
\text { menyebutkan } \\
\text { bahwa beliau } \\
\text { adalah orang } \\
\text { yang tsiqah }\end{array}$ \\
\hline
\end{tabular}

Tabel 4. Hadis shahih Bukhari Nomor 5289, hal ini dilihat dari proses tahammul wa al ada' menggunakan hadasana dan akhbarana yang mengindikasikan bahwa mereka bertemu langsung. Hadis riwayat Bukhari ini muttasil (bersambung). Dan juga dilihat dari adanya hubungan antara guru dan murid pada masing-masing perawi dilihat dari negeri hidup dan tahun wafatnya yang sangat memungkinkan terjadinya pertemuan antara guru dan murid (Qomarullah, 2016). Dan juga tidak terjadi keterputusan sanad. Para ulama juga menilai para periwayat adalah rawi yang tsiqah (adil dan dhabit) dan juga tidak ditemukan syadz dan ilat. Jadi hadis tentang pembatasan sosial ketika terjangkit wabah adalah hadis yang maqbul dan bisa dijadikan hujjah (Sanusi, 2014).

Abu Isa berkata dalam kitab syarah aunul ma'bud hadis semakna diriwayatkan dari Ibnu Mas'ud, Abu Hurairah, Abu Khuzaimah dari bapaknya dan Ibnu Abbas. Dan ini merupakan hadits hasan shahih. Rasulullah Saw. bersabda "setiap penyakit bisa disembuhkan." Hanya saja terkadang kita tidak bisa menemukan obat yang tepat (Azhim, 2018).

Tidak semua hadis memiliki asbabul wurud. Ada beberapa hadis memiliki asbabul wurud yang khusus, tegas dan jelas, sementara yang lainnya tidak. Begitupun dengan hadis yang ini tidak ditemukan asbabul wurud yang khusus. Sebagai alternatif hadis ini dapat dikaji menggunakan metode historis, sosiologis, antropologis bahkan psikologis sebagai alat analisis untuk memahami hadis. Hal ini didasarkan pada anggapan bahwa Nabi Saw. tidak pernah bersabda tanpa adanya faktor sejarah, budaya dan peristiwa (Fadli, 2014).

Syekh Muhammad bin Salih al-Uthaimin Rahimahullah menjelaskan bahwa perawatan medis sangat diperlukan. Meninggalkan berarti menempatkan diri anda dalam bahaya. Di sisi lain, hal ini berarti sakit adalah menjalani cobaan, cobaan dari Allah Swt. (Ilyas, 2020). Oleh karena itu, kita harus merespon dan mencari pengobatan untuk setiap penyakit, termasuk jika kita terkena wabah.

Menurut Ibn Qayyim ungkapan "setiap penyakit bisa disembuhkan" artinya bisa universal. Oleh karena itu, termasuk penyakit yang fatal dan berbagai penyakit yang tidak dapat disembuhkan oleh dokter karena tidak ada obatnya. Lalu Ibn Qayim menegaskan "Allah telah menciptakan obatobatan untuk mengobati semua penyakit ini. Namun, ilmu tentang obatobatan ini tidak diturunkan kepada umat manusia" (Azhim, 2018). 
Menurut Ibn Qayyim, pernyataan Nabi bahwa "setiap penyakit harus disembuhkan" tidak hanya mendorong orang sakit, tetapi juga menginspirasi para dokter yang merawat mereka, dan menyarankan untuk mencari nasihat medis dan investigasi medis (Azhim, 2018). Karena ketika seorang pasien merasa memiliki keyakinan bahwa ia dapat disembuhkan ia akan mengandalkan semangat pengharapan tanpa keputusasaan membuatnya berhasil (Azhim, 2018).

Imam al-San'ani menjelaskan bahwa hadis ini adalah pedoman dari Rasulullah Saw. yang membahas tentang perlunya berobat dan menemukan penawar penyakit. Bahkan hal ini menjadi penting untuk memperlajari sebab dan musababab penyakit serta kesembuhannya. Hal ini adalah prinsip penting untuk senantiasa percaya pada Allah Swt. (Akbar, 2020).

\section{Analisis Hadis Praktik Pencegahan Wabah Covid-19}

Setelah dilakukan kajian pada hadis pertama dari mulai takhrij, asbabul wurud dan juga syarah hadis tersebut sangat relevan dengan situasi pandemi Covid-19 yaitu berkenaan dengan aturan pembatasan sosial di negara terjangkit Covid-19, dimana beberapa wilayah di Indonesia menerapkan PSBB sebagai upaya membatasi gerak sosial untuk memutus mata rantai penyebaran Covid-19 (Hairi, 2020). Pemerintah meyakini bahwa penerapan PSBB sebagai cara yang paling efektif untuk menghentikan mata rantai penyebaran Covid-19. Pemerintah juga menghimbau para pejabat baik daerah maupun pusat untuk melakukan pembatasan kegiatan pada sektor tertentu yang mengundang kerumunan (Fauzi, 2020).

Perubahan sosial yang diterapkan di Indonesia sama dengan perubahan sosial yang diberlakukan kota Syam pada saat terjangkit wabah Thaun dimana pemerintahan Syam pada saat itu melarang keras diadakannya kagiatan-kegiatan yang mengundang banyak orang apalagi dari luar daerah. Meskipun untuk kepentingan negara dan pemerintahan. Sebagai penyakit yang menular dan mematikan, baik Tha'un maupun Covid-19 memiliki resiko yang cukup berbahaya dan mengancam (Ridho M. R., 2020). Oleh karena itu, Islam sangat menganjurkan agar setiap individu atau kelompok harus ekstra hati-hati untuk menjaga jarak dari setiap orang, tempat atau benda yang mungkin menyebar. Berkaitan dengan hal tersebut, Imam al-Asqalani menegaskan bahwa dalam keadaan seperti itu, dilarang mengadakan kegiatan yang mengundang keramaian bahkan dalam bentuk kegiatan keagamaan (Qudsy, 2020).

Hadis kedua berkenaan dengan pemisahan antara yang sehat dengan yang berpotensi terjangkit penyakit relevan dengan kebijakan isolasi mandiri (karantina) yang diperuntukan untuk orang yang sakit dan setelah pemeriksaan ditemukan keberadaan virus Sars-CoV-2 di dalam tubuhnya. 
Dan mempunyai potensi virus tersebut akan menyebar ke seluruh tubuhnya dan orang lain (Saputra, 2020). Isolasi juga sangat diharuskan bagi siapa yang telah menjalankan rapid test dan hasilnya positif, serta orang yang memiliki gejala atau keluhan serupa gejala Covid-19 seperti suhu tubuh di atas 38,5 derajat celcius, batuk, dan saluran udara yang tidak nyaman.

Karantina dilakukan dengan tidak berjalan-jalan, dan hanya tinggal di rumah selama kurang lebih dua minggu. Menurut Kementerian Kesehatan, karantina mandiri dilakukan di rumah untuk terpisah dari anggota keluarga lainnya agar tidak berpotensi terjangkit Covid-19 (Toshepu, 2020). Modus isolasi tampaknya sederhana, tetapi sulit bagi semua orang untuk melakukannya. Namun, menurut Kementrian Kesehatan isolasi merupakan cara yang efektif untuk mencegah penyebaran penyakit dan mencegah penyebarannya (Rahmah, 2020). Oleh karena itu, isolasi diri sangat penting sebagai langkah preventif.

Hadis mengenai karantina memiliki dua redaksi yang bertolak belakang namun seperti yang telah dijelaskan di atas bahwa pendapat yang paling kuat yakni bahwa maksudnya adalah menyerahkan penularan kepada Allah semata. Menurut Imam an- Nawawy meski begitu, kita tetap diperintahkan untuk menghindari jika penyakit ini memang berbahaya, jangan sampai sakit. Ini karena Islam memerintahkan manusia untuk menjaga keselamatan jiwa dan hidupnya. Jangan tertular penyakit, terutama penyakit berbahaya seperti wabah. Islam sendiri mendorong mereka yang beriman untuk menghindari kerugian, karena itu adalah bagian dari prinsip utama agama. Menurut Gus Mus sebagai tokoh agama, tugas menjaga dari bahaya (wabah) merupakan upaya melindungi diri sendiri dan orang lain dari penyakit menular (Firdaus, 2020).

Hadis ketiga berkenaan dengan anjuran untuk berobat bagi yang sakit relevan dengan upaya vaksin yang dirancang untuk preventif Covid-19. Satgas Covid-19 menyatakan bahwa penyebaran dapat dihentikan jika adanya deteksi dini, isolasi dan pengobatan tepat waktu untuk menciptakan implementasi sistem yang kuat untuk memutus mata rantai penyebaran Covid-19 (Griffhits, 2020). Pada redaksi “Sesungguhnya Allah telah menurunkan penyakit dan obat, dan menjadikan bagi setiap penyakit terdapat obatnya, maka berobatlah" dapat diketahui bahwa memahami mekanisme penyakit dan antisipasi pencegahannya merupakan salah satu bentuk takwa kepada Allah Swt. karena setiap yang Allah Swt. ciptakan memiliki atribut tetap (spesifikasi), termasuk virus (Azhim, 2018). Pada masa Khilafah Islam, dana wakaf menyumbang hampir 30\% dari pendapatan Baitul Mal. Besarnya dana tersebut memungkinkan berkembangnya pelayanan kesehatan dan penelitian karena tidak ada beban untuk mengembalikan manfaatnya (Kasdi, 2016). 
Mengingat kemajuan dan perkembangan aktivitas sosial manusia, permasalahan penyakit menular juga mengalami kompleksitas penanganan, penyebaran dan dampak yang ditimbulkannya. Masalah yang dihadapi saat ini tidak sesederhana di masa lalu. Oleh karena itu, permasalahan terkait pengobatan penyakit menular dalam hal ini kasus Covid perlu diimbangi dengan cara yang lebih modern, dengan tetap memperhatikan derajat keburukan (kerugian) dan kemanfaatannya (maslahah). Dalam hal ini, sebagai upaya perlindungan mengenai mengjangkitnya Covid-19, seluruh dunia berkomitmen melaui pemerintah, partisipasi perusahaan bioteknologi dan para ilmuwan untuk menciptakan vaksin Covid-19 dan sudah diberikan kepada masyarakat secara bertahap (Sari, 2020). Oleh karena itu, semua hal yang berkenaan dengan SARS-CoV2 (virus penyebab Covid-19) dan eksplorasinya sangat penting untuk menghasilkan vaksin yang efektif (Shafa, 2021). Rencana lain terkait vaksin Covid-19 masih dalam proses tahap pengembangan (Med, 2020). Ulasan ini meringkas perkembangan terkait vaksin SARS-CoV-2 sebagai bentuk preventif terhadap Covid-19.

Kajian-kajian mengenai hadis-hadis pencegahan Covid-19 telah banyak dibahas oleh penelitian sebelumnya dengan berbagai metode dan pendekatan. Hal ini mengindikasikan bahwa hadis telah mengintruksikan praktik pencegahan wabah penyakit menular meliputi pembatasan sosial, karantina, dan melakukan pengobatan. Hasil dari penelitian ini diharapkan berguna bagi perkembangan keilmuan dalam bidang kesehatan dan berguna sebagai salah satu pembuktian kebenaran hadis-hadis sains yang diakui oleh dunia medis.

\section{Kesimpulan}

Wabah dan pandemi merupakan penyakit menular yang menjangkit secara bersamaan di berbagai negara, wabah penyakit menular dalam dunia Islam dikenal sebagai wabah Thau'n. Setelah dilakukan kajian terhadap hadis-hadis mengenai pencegahan wabah penyakit menular dengan menggunakan metode syarah hadis tematik dapat diketaui bahwa ditemukan tiga hadis tentang pencegahan wabah penyakit menular dalam Shahih Bukhari nomor 5289, 5330 dan Sunan Abu Dawud nomor 3376. Hadis-hadis tersebut merupakan hadis yang maqbul dan dapat dijadikan hujjah. Pemahaman hadis-hadis tentang pencegahan penyakit menular berkenaan dengan pembatasan sosial, karantina, dan pengobatan adalah langkah yang paling efektif untuk memutus mata rantai penyebaran wabah penyakit menular Covid-19. Penelitian ini diharapkan memiliki implikasi manfaat bagi pengembangan khazanah pengetahuan Islam khususnya dalam bidang kajian hadis. Diakui penelitian ini memiliki keterbatasan dalam pelaksanaan syarah hadis dengan pendekatan tematik ini sehinga diperlukan penelitian lebih lanjut secara komprehensif, integral dan 
mendalam. Penelitian ini merekomendasikan diadakannya penelitian yang lebih mendalam terutama bagi para pengkaji hadis sains dengan pendekatan keilmuan lain yang akan membuka pemahaman yang lebih luas mengenai topik ini.

\section{Daftar Pustaka}

Abdullah, A. (2021). Pengantar Metodologi Penelitian Hadis Tematik. Malang: Maknawi.

Akbar, D. L., \& Budiyanto, B. (2020). Konsep kesehatan dalam al-qur'an dan hadis. Al-Bayan: Jurnal Ilmu al-Qur'an dan Hadist, 3(2), 157-173.

al-'Asqalani, S. I. (1989). Badzlu al-Ma'un Fi Fadhli al-Tha'un. Riyadh: Darul Asimah.

al-'Asqalani, S. I. (2010). Fathul Bari. Jakarta: Pustaka Imam Asy-Syafi'i.

al-Asqalani, I. H. (2017). Asbabul Wurud Hadis. Kotamobagu, Sulawesi Utara, Indonesia.

Anas, M. (2013). Metode Memahami Hadis-hadis Kontradiktif. Mutawatir Jurnal Keilmuan Tafsir Hadits.

Andrija, D. F. (2020). Hukum Seputar Covid-19 dalam Tinjauan Syari'ah.

Azhim, A. A.-T. (2018). Aunul Mabud. Jakarta: Pustaka Azzam.

Birbiq, H. (2020). Takhirij Hadis (metode penelitian sumber-sumber hadis untuk meminimalisir pengutipan hadis secara sepihak). Ar-Risalah media keislaman,pendidikan dan hukum islam.

Bukhari, M. b. (n.d.). Jami' Shahih al-Bukhari.

Chandra, D. B. (2013). Kontrol Penyakit Menular pada Manusia. Jakarta: Penerbit Buku Kedokteran EGC.

Cornad, L. I. (2021). Thaun dan Waba (konsep plague dan pastilence dalam awal periode islam). Journal American University of Berut .

Darmalaksana, W. (2020). Cara Menulis Proposal Penelitian. Jurnal Fakultas Ushuluddin UIN Bandung.

Darmalaksana, W. (2020). Corona Hadis. Jurnal Fakulfas Ushuluddin UIN Bandung.

Darmalaksana, W. (2020). Metode Penelitian Kualitatif Studi Pustaka dan Studi Lapangan. Pre-Print Digital Library UIN Sunan Gunung Djati Bandung.

Darmalaksana, W. (2020). Penelitian Metode Syarah Hadis Pendekatan Kontemporer: Sebuah Panduan Skripsi, Tesis, dan Disertasi. Diroyah: Jurnal Studi Ilmu Hadis, 59-68.

Darmalaksana, W. (2020). Rekam Proses Kuliah Online: Metode Penelitian. Bandung: UIN Bandung.

Darmalaksana, W. (2021). Takhrij and Syarah Hadis About Argotechnology : Senna Leaf Plant in Covid-19 Infection. International Journal Of Culture And Modernity.

Effendi, D. I. (1987). Pencegahan Penyakit Menular. Jakarta : Penerbit Bratara 
Karya Aksara.

Fadli, A. (2014). Asbab Al-Wurud: Antara Teks dan Konteks. ElHikam, 7(2), 379-394.

Fauzi, A. (2020). Implementasi Pembatasan Sosial Berskala Besar, Sebuah

Kebijakan Publik Dalam Penanganan Pandemi COVID-19. Jurnal Ilmu Administrasi Negara, 16(1), 174-178.

Firdaus, F. (2020). Virus Corona Dalam Perspektif Sunnah. Jurnal Al-

Mubarak: Jurnal Kajian Al-Qur'an dan Tafsir, 5(1), 13-29.

Ghazali, N. M., Adawiyah, R., \& Ahmad, M. H. (2020). Tematik Hadis Wabak Dalam Kitab Sahih Al-Bukhari.

Pakpour, A. H., \& Griffiths, M. D. (2020). The fear of COVID-19 and its role in preventive behaviors. Journal of Concurrent Disorders, 2(1), 5863.

Hairi, P. J. (2020). Implikasi Hukum Pembatasan Sosial Berskala Besar Terkait Pencegahan COVID-19. Info Singkat Bidang Hukum, 12 (April), 1-6.

Ilyas, F. S. (2020). Dampak dan pencegahan Wabah Covid-19 Perspektif Sains dan islam. Jurnal Perspektif UIN SGD Bandung.

Izzan, A. (2012). Studi Takhrij Hadis (Kajian Tentang Metodologi Takhrij Hadis dan Kegiatan Penelitian Hadis). Bandung: Humaniora.

Kasdi, A. (2018). Dinamika Pengelolaan Wakaf di Negara-Negara Muslim. ZISWAF: Jurnal Zakat dan Wakaf, 4(1), 73-86.

Hauqola, N. (2013). Hermeneutika Hadis: Upaya Memecah Kebekuan Teks. Jurnal Theologia, 24(1), 261-284.

bin Kurdian, N. K. (2014). Kontradiksi Hadis Penyakit Menular Prespektif Ulama Hadis Dan Relevansinya Dengan Dunia Medis. Al-Majaalis: Jurnal Dirasat Islamiyah, 2(1), 1-32.

Lu, X., Zhang, L., Du, H., Zhang, J., Li, Y. Y., Qu, J., ... \& Wong, G. W. (2020). SARS-CoV-2 infection in children. New England Journal of Medicine, 382(17), 1663-1665.

Mosiba, R. (2016). Masa Depan Hadis Dan Ilmu Hadis. Jurnal Inspiratif Pendidikan, 5(2), 316-331.

Muhyiddin, M. (2020). Covid-19, New Normal, dan Perencanaan Pembangunan di Indonesia. Jurnal Perencanaan Pembangunan: The Indonesian Journal of Development Planning, 4(2), 240-252.

Mukharom, M., \& Aravik, H. (2020). Kebijakan Nabi Muhammad Saw Menangani Wabah Penyakit Menular dan Implementasinya dalam Konteks Penanggulangan Coronavirus Covid-19. SALAM: Jurnal Sosial dan Budaya Syar-i, 7(3), 239-246.

Nilasari. (2020). Pengantar Studi Hadis Tematik. Jurnal Hadis Universitas Islam Negeri Hasanudin.

Noor, N. N. (2014). Epidemiologi. Jakarta: Rineka Cipta.

Nur, S. (2017). Jenis dan Langkah Penelitian Hadis. NUKHBATUL' ULUM: 
Jurnal Bidang Kajian Islam, 3(1), 19-25.

Nurhayati, T., \& Aji, R. H. S. (2020). Emansipasi Melawan Pandemi

Global: Bukti Dari Indonesia. ADALAH, 4(1).

Piddock, C. (2013). Wabah Sains Menjaga Kesehatan Global. Washington .

Qomarullah, M. (2016). Metode Takhrij Hadis Dalam Menakar Hadis

Nabi. El-Ghiroh Jurnal STAI lubuklinggau.

Qudsy, S. Z., \& Sholahuddin, A. (2020). Kredibilitas Hadis dalam COVID-

19: Studi atas Bażl al-Mā' ūn fi Fadhli al-Thāun karya Ibnu Hajar al-

Asqalany. AL QUDS: Jurnal Studi Alquran dan Hadis, 4(1), 1-18.

Putri, N. W., \& Rahmah, S. P. (2020). Edukasi Kesehatan untuk Isolasi

Mandiri dalam Upaya Penanganan COVID-19 di Kanagarian Koto

Baru, Kabupaten Solok. Jurnal Abdidas, 1(6), 547-553.

Rakhmadi, A. j. (2020). Kepustakaan Medis Pandemik di Dunia Islam.

Sumatera: OIF UMSU.

Ridho, M. R. (2020). Wabah Penyakit Menular dalam Sejarah Islam dan

Relevansinya dengan Covid-19. JUSPI (Jurnal Sejarah Peradaban Islam), 4(1), 24-33.

Romadona, K. (2015). Penanganan Penyebaran Virus Ebola di Afrika Barat oleh World Health Organization (WHO).

Sanusi, A. (2014). Takhrij Hadis. Jurnal Madani Publishing.

Saputra, M. R., \& DR, R. N. R. (2020). Telemonitoring Perburukan Gejala pada PDP COVID-19 Karantina Mandiri Berbasis IoT (Doctoral dissertation, Universitas Muhammadiyah Surakarta).

Sari, I. P., \& Sriwidodo, S. (2020). Perkembangan Teknologi Terkini dalam Mempercepat Produksi Vaksin COVID-19. Majalah Farmasetika, 5(5), 204-217.

Shafa, A. (2021). Microneedle :Teknologi Baru Pengantar Vaksin Covid-19. Jurnal Majalahn Farmasetika.

Siegrist, C. A. (2021). Vaccine Imunology. Melbroune: Saunders El Sevier Publishing.

Sihab, Q. (2020). Corona Ujian Tuhan. Jakarta : Penerbit Lentera Hati.

Toshepu, R. (2020). Corelation Between Weater amd Covid-19 Pandemic in Jakarta Indonesia. Jurnal Elshiver Science of the Total Environment.

Wiyono, A. H. (2020). KAJIAN TAHRIJ HADITS DALAM STUDI ISLAM. SAMAWAT, 3(2).

Zaenuri, A. (2020). Konsepsi Fikih Dakwah Jamā'ah Tablīgh pada Masa Pandemi Covid-19: Telaah Gerakan Dakwah Jamā'ah Tablīgh

Gorontalo. JIL: Journal of Islamic Law, 1(2), 135-157. 